\title{
EDITORIAL
}

\section{DISCURSO INAUGURAL DE LA FACULTAD DE EDUCACIÓN U.D.C.A}

\author{
Abril 28 de 2015
}

\author{
Germán Anzola Montero \\ Rector
}

Fue un honor para la Universidad de Ciencias Aplicadas y Ambientales U.D.C.A aprovechar la celebración de la Vigésima Octava Feria del Libro, para presentarle al país la creación de nuestra nueva Facultad de Ciencias de la Educación. No podía ser ajena la Institución que dirijo y que ha dedicado la mayoría de sus esfuerzos al campo del medio ambiente y de sectores estratégicos, a contar con un programa que, para nosotros como académicos y educadores, representa lo más valioso que un país, que realmente piensa en su futuro, pueda ofrecer a sus ciudadanos, como es la formación de profesionales, licenciados y posgraduados en educación. De esta manera, aspiramos utilizar todos nuestros esfuerzos y recursos para que también nos podamos constituir como líderes en el compromiso de elevar la calidad de la educación colombiana, en todos sus niveles.

En este orden de ideas, es nuestro propósito mejorar la docencia básica y media, mediante la creación de programas de Licenciatura en Ciencias Naturales y Educación Ambiental, aprovechando los recursos ya existentes en la U.D.C.A, pues consideramos que no solo es responsabilidad del mundo y del Estado, sino de las Universidades, propender para que realidades ambientales, entre otras, el cambio climático, sea objeto de la mayor consideración y estudio, pues para nadie es un secreto que si no se utilizan los mecanismos adecuados para su control, se puede constituir en una verdadera amenaza. De igual manera, daremos comienzo a nuestra Maestría en Educación Ambiental y Especialización en Docencia para la Educación Superior, como generadores de conocimiento e investigación aplicada y transferible, a fin de fortalecer a los futuros docentes en estos temas, para que, de esta forma, sean beneficiarios los alumnos que posteriormente vayan a recibir su conocimiento.
Queremos y es nuestro propósito decidido, ser protagonistas y no seguidores de caminos ya trillados, a fin de auscultar las nuevas realidades que están por venir, como son la convivencia pacífica en una sociedad que definitivamente sienta sus bases en el tríptico: Ciencia, Tecnología e Innovación.

En esta solemne inauguración del nuevo Proyecto Educativo queremos informar a los futuros estudiantes que será nuestra obligación hacer de ellos, educadores de excelencia, mediante una educación crítica y reflexiva sobre todos los estamentos, llámense social, político, económico, cultural, entre otros.

De igual manera, seremos consistentes en el propósito de formar educandos integrales y respetuosos del pensamiento ajeno, aupados, como ya lo dijimos, por los valores que nos han caracterizado, como son la honestidad, la ética y la calidad de la prestación del servicio educativo.

Como corolario, reitero ante esta distinguida y respetable concurrencia, que nuestro más hondo deseo es que podamos, congregar el medio ambiente con la educación, a fin de educar a seres humanos respetables y con condiciones morales, para que, a su vez, éstos puedan transmitir el conocimiento a quienes van a representar el futuro de la patria.

\section{MUCHAS GRACIAS}

